International Journal of Canadian Studies

Revue internationale d'études canadiennes
INTERNATIONAL JOURNAL OF CANADIAN STUDIES

REVUE INTERNATIONALF D'ÉTUDES CANADIENNES

\title{
From Contented Civility to Contending Civilities: Alternatives to Canadian White Civility
}

\section{Daniel Coleman}

Numéro 38, 2008

Borders, Migrations and Managing Diversity: New Mappings

Frontières, migrations et gestion de la diversité : nouvelles

cartographies

URI : https://id.erudit.org/iderudit/040815ar

DOI : https://doi.org/10.7202/040815ar

Aller au sommaire du numéro

Éditeur(s)

Conseil international d'études canadiennes

ISSN

1180-3991 (imprimé)

1923-5291 (numérique)

Découvrir la revue

Citer cet article

Coleman, D. (2008). From Contented Civility to Contending Civilities: Alternatives to Canadian White Civility. International Journal of Canadian Studies / Revue internationale d'études canadiennes, (38), 221-242. https://doi.org/10.7202/040815ar 


\section{Daniel Coleman}

\section{From Contented Civility to Contending Civilities: Alternatives to Canadian White Civility}

The Author Meets Critics panel session on White Civility: The Literary Project of English Canada at the Association for Commonwealth Languages and Literature Studies (ACLALS) conference in Vancouver, August 2007, provided a wonderful stimulus to my thinking, not just about the book, but about the ongoing project of critically dismantling the assumptions of White supremacy in Canada. ${ }^{1}$ What follows is an amalgamation of the comments I offered at the panel session itself and further thoughts sparked by the comments and questions offered by the three colleagues who performed the role of "critics"-George Elliott Clarke, Margery Fee, and Robert Young - as well as by audience members that day. I have written the paragraphs that follow in such a way that those who were not at the session will have some sense of the context of our discussion, and those who were there will, I hope, see how the day's discussion has furthered my own thinking since then. George, Margery, and Robert, too, may have readjusted their comments since we met in Vancouver, but I will have to rely here upon what they said at the session. Although they raised a variety of points well worth pursuing, let me focus, after a brief overview of the book's general project, on three broad topics touched upon in different ways by George, Margery, and Robert. These were elaborated in the ensuing round-the-room discussion, and I think they are crucial for further consideration. The first rises from Robert's attention to the genealogical lines of terms central to the analysis in White Civility - particularly the ethno-national designations of Britishness and Englishness, and the relations between the concepts of civility and civilization. The second rises out of George's and Margery's concern that the book's history of White writers' production and reproduction of White civility can repeat the marginalization and silencing of non-White writers' criticisms of and alternatives to it. $^{2}$ The third rises out of all three critics' querying of the book's call for "wry civility." "Why civility?" asks George. If we want a different ethic, furthers Margery, quoting Thomas King, why not "Tell a different story"?

International Journal of Canadian Studies / Revue internationale d'études canadiennes 38,2009 


\section{The Project of White Civility}

Before engaging with these three areas of concern, let me quickly summarize, for the benefit of those who have not read the book, its central project. White Civility argues that civility is an obsession for White Canadians; that whiteness in Canada is consistently preoccupied with shoring up, measuring, asserting, and reasserting itself by means of the discourse of civility. In a very real sense, White Canadians have tried to create civility in their own image: this has been the central project of invader-settler subjectivity in Canada. White Canadian civility is nervous; it has to disavow its histories of racialized violence to generate its image of Canada as a society-in the famous terms of Section 91 of the British North America Act-of peace, order, and good government. It needs to disavow the literal and cultural genocide practiced against Indigenous peoples that constitutes the foundation of White invader-settler culture, and it needs to disavow the ongoing, racialized violence that has maintained White supremacy in the positions of control and power in Canada. The book argues that civility in Canada is under particular pressure: White Canadians have turned to it repeatedly to show why we are more civil than the citizens of the manifest-destiny-driven United States or imperially tarnished Britain. Referring to history, Canadians have cited the constitutional monarchy of our British heritage to show why we are more civil than mob-ruled, revolutionary Americans, and we have turned to the vigour of our North American climate or our supposedly classless society to show why we are more civil than the British. More recently, we offer our multiculturalism policy, our high ranking on the United Nations' lists of favourable places to live, or our role as international peace-keepers as evidence that we are more civil than anybody else in the world. This tendency to comparison marks civility's conceptualization as a moral-ethical concept (well-mannered, orderly, just society) and a temporal achievement (Canada as "ahead" of other nations' civil arrangements). ${ }^{3}$ White Civility observes that these claims for comparative civility are particularly shrill in Canada; Canadians, conscious of being citizens of a "younger" nation than their competitors, make up for feeling belated in the race between nations for recognition as the most progressive civilization by insisting, more forcefully than others, on the signs of our own civility.

These shrill proclamations become ironic when we observe that civility itself is structurally contradictory. This is to say that in order to maintain the civil sphere in which everyone can expect peace and justice, civility guards its borders; it violently suppresses internal and external threats to its supposedly egalitarian polity. In this sense, civility purveys an overt story of universal peace, order, and good government while it deploys a covert, disavowed story of violent suppression of alternatives 
for what and who might constitute the civil sphere. ${ }^{4}$ One need only recall the harsh suppression of Riel's provisional government in Manitoba in 1870 , the rejection of Sikh immigrants from Vancouver harbour in 1914, or the exclusion of Chinese immigrants until after the Second World War to see how the margins of civility in Canada have consistently been policed along the borders of whiteness. White Civility argues that Canadian civility, then, is paradoxically an internally striated universalism. In sum, the project of the book is a critique of Canadian concepts of civility by means of an historical examination of the ways in which the interlinked codes of whiteness and a particularly Canadian-made brand of Britishness have organized and managed an internal racial hierarchy. The book attempts to do this work by reading popular and influential Canadian literary and social texts from the mid-nineteenth to the midtwentieth centuries. It traces how four allegorical personifications of the nation-the Loyalist brother, the Scottish orphan, the muscular Christian, and the maturing colonial son-popularized the values of White civility as a kind of national pedagogy that has resonances in Canadian public culture to this day.

\section{Racialization and Sloppy Categories}

Robert Young's comments in the session laid out a first line of inquiry when he questioned how precisely the historical development of some of White Civility's key terms is delineated, especially Englishness and Britishness (and their relation to the genealogies of Angles, Saxons, Irish, Scots, and French), but also civility and civilization. I will address the first pair here and take up the discussion of civility and civilization later in this writing. I am grateful for Robert's questions because precision is an important consideration in any work that wants to take up the genealogies of race, ethnicity, and discrimination. Race has had many meanings throughout its history (from something approximating what we would now think of as biological species to concepts we would now think of as cultural, religious, class-oriented or ethnic) and not distinguishing among these various meanings can cloud the specific operations of racism (as compared to religious bigotry or cultural intolerance, for example). If ethno-national categories such as British, Scottish, or English are not set in their specific historical contexts, they become large and imprecise, and the tensions and negotiations among them become obscured. They become sloppy.

It is precisely the history of sloppiness, however, that is central to my investigation. For one thing, a true and reliable "origin" for any ethnoracial-national category will always be illusive. Take Scottishness, for example, which of course subdivides into Highlanders and Lowlanders, not to mention Catholics and various branches of Presbyterianism. 
Scottishness traces back, even further, to Irish migrants (Trevor-Roper 15), who, in turn, were descended from even earlier pre-Celtic people from Scotland mixed with Celts from what the Romans had called "Gaul" (see "The Celts"). This endless unravelling of the thread of origins, as Étienne Balibar has observed, undermines the purity of every nationalist or racial project of "ethnogenesis"; every such category rises, not from the solid foundation of a finally identifiable origin, but instead from the process of narration and renarration itself-making it, in Balibar's terms, a "fictive ethnicity" ("The Nation Form" 224). As White Civility is at pains to show, then, categories such as British and English are characterized by this kind of sloppy non-precision, especially as these terms were used by invader-settlers in the colonies. Indeed, this elasticity is precisely what made these terms useful for racial projects such as that of English Canadian White supremacy. As historians such as Donald Akenson have shown, the concept of Britishness as a cultural or national identity does not originate in the British Isles. Although the term was used to define the geographical location of the islands as early as the sixteenth century, the sectional peoples of Great Britain did not call themselves "British" before the nineteenth century, for this term was invented in the colonies and referred to a pan-ethnic unity that did not in fact exist in the British Isles. Britishness worked well for the peripheral peoples of the United Kingdom-the Scots, Irish, and Welsh of the Celtic margins-as they worked their way into positions of power and influence in the colonies. ${ }^{5}$ The chapter on the Scottish orphan in White Civility provides an historical genealogy for the way in which Scottish Canadians made use of the loose category of Britishness to oil the wheels of their ascendancy to political, social, and economic power in Canada. Being British subjects in a British colony gave them a leg up over "foreigners" such as Eastern and Southern Europeans and other non-English-speaking settlers in Canada. ${ }^{6}$

Moreover, "English" itself is a sloppy category: the slippage between English as an ethnicity and English as a language creates an ambiguity to the term which has enabled it to pick up where Britishness left off as a pan-ethnic concept and to extend its reference even further. Thus, in Canada, the two founding races theory of French and English origins inherited from Lord Durham's report (1839) has meant that all Canadian territory outside Quebec and its inhabitants collectively have become colloquially known as "English Canada." This nomenclature results directly from the dominance of the English-speaking majority outside of Quebec, regardless of individuals' ethnic backgrounds and despite the predominance of First Peoples and languages in regions such as Labrador and Northern Canada. By these means, Britishness and Englishness became loose and fluctuating categories of identification that gave a whole variety of Canadians access to the legitimating codes of civility associated with the Scottish-to-British-to-English continuum. But only if 
these Canadians qualified as White. The power of this particular linkage of whiteness and British-Englishness in the Canadian popular imagination explains why a writer such as Myrna Kostash, who has highlighted throughout her entire career her Ukrainian-Marxist-feminist distance from the "English" mainstream and seen this distance as a basis for solidarity with other marginalized people, nonetheless found herself unwillingly lassoed into representing the White mainstream during the debates over the Writing Thru Race conference in 1994 that took place when she was Chair of the Writers Union of Canada. As the terms of cultural debate shifted from ethnic minority status in the 1970s and 1980s to an increased emphasis on race and colour in the 1990s, Kostash writes, "I had discovered that; in the new terms of the discourse, I was white. I was a member of the privileged majority. I was part of the problem, not the solution" (92). Her whiteness, added to her success as a writer in the English language, had overpowered her non-English ethnicity, regardless of her explicitly resistant self-positioning.

The sloppiness of these national-racial-ethnic terms, in other words, is precisely what has given them their strength and agility in Canadian cultural politics. In this context, Stuart Hall's discussion of race as a "floating signifier" (in Sut Jhally's film of the same title) helps us see why genealogical sloppiness is central to the operation of racial projects. Race, as many scholars have shown us, is not an essence, not grounded in a specific gene, bloodline, or family inheritance. It floats, changing in salience with the context. One day you're a Canadian citizen, after Pearl Harbour you're an Enemy Alien Japanese; you've long been considered Black Irish, but when you compete for a job with African Americans, suddenly you're White; one day you're a Canadian citizen, after September 11, 2001 you're an Islamic terrorist. Race may be a floating signifier, but this does not mean it is easily dislodged or erased, for race is also tenacious. As Malcolm X famously said: "Racism is like Cadillac; there's a new model every year." The designations of race float from articulation to articulation, attaching this year to skin pigmentation, next year to religion, and the following to social class, but they do not vanish for all their mobility. The question was raised from the floor at our panel session whether the debate over Turkey's joining the European Union could be traced to a racist designation of Turks as non-Europeans and non-Whites or whether it was more derived from disapproval of Turkey's uncertain history of democracy, for example, or perhaps suspicion of the non-liberal influence of the Muslim members of its population. The discussion, in my view, offered a clear example of the way in which the categories of race float from genetic ancestry to national heritage to religious history to political form-all within a generalized, assumed discourse of civility. The rationale for exclusion may use the language of culture or political tradition, but it's not usually difficult to predict who 
will be questioned, if not excluded. ${ }^{7}$ The signifiers of race and ethnicity float and are sloppy, and this slippage is central to the process of racemaking, whether it occurred in the Canadian elaboration of a certain form of Britishness which has animated the idea of White Canadian civility ever since, or whether it appears in the various attempts of the Indian Act over the past century and a half to define exactly what an "Indian" is.

The sloppy history of the signifiers of race-ethnicity-civility-culture makes them dynamic, constantly shifting, non-static. Thus effecting the final emancipation from the entire discourse of raciology that Paul Gilroy calls for in Against Race is as impossible to achieve as the final elimination of racism. If the terms and strategies of racialization are constantly shifting, then anti-racist work cannot remain completely focused on any single target, for the target, predictably, will change. Anti-racism, then, must be a way of life, one that recognizes that no sooner will one form of racism be addressed or fall into decline than another one will emerge. But the dynamic sloppiness of raciology also means that anti-racist critics can intervene in its operations. It can be interrupted and derailed-it has been in the past, and it can be again.

\section{Contending Civilities}

Because this is the case, because the assumptions of raciology can be derailed, I am grateful to Margery and George for pointing out a second broad area of concern: White Civility's method of tracing the genealogy of Canadian White supremacist thinking in writings by White writers. On the one hand, it is essential for anti-racist criticism to trace how the beneficiaries of Canada's racial hierarchy created and naturalized that hierarchy, for this is precisely the kind of racializing work that goes unexamined and is assumed in the cultural mainstream. Denaturalizing what appeared to be natural in its own home remains necessary. Nonetheless, a danger exists that this focus on White self-constructions can "cover," as George put it, the analyses and criticisms of White racial dominance in Canada by non-White authors, much like White musicians since the 1950s have made successful careers out of covering (and thus containing and obscuring) Black-authored hits. These non-Whiteauthored critical expressions, as both Margery and George pointed out, are not restricted to recent works by currently well-known writers and critics from M. NourbeSe Philip and Taiaiake Alfred to Sherene Razack and Richard Fung. Margery referred to Harold Cardinal's protest of Canadian racism in The Unjust Society (1969), while George gestured to Ida Cecil Greaves' The Negro in Canada (1930) as instances of much earlier critical interventions in the self-exonerating discourses of Canadian White civility. And they could have gone on: Levi General 
circulated "The Redman's Appeal for Justice" in 1923 among members of the League of Nations when he, a Cayuga chief with the title of Deskaheh, led a delegation from Six Nations on the Grand River in Ontario to London and Geneva in an attempt to get the Iroquoian Confederacy recognized as an independent state and thereby avoid being annexed by an increasingly aggressive Canada (see Titley 110-34 and Woo); his pamphlet echoed many of the concerns laid down in writing in the late $18^{\text {th }}$ century by the Mohawk leader Joseph Brant (see Monture). These writings in turn were contemporaneous with the statements of frustration with White Canadian discrimination expressed by the earliest Black Loyalist writers collected in George's two volume anthology, Fire on the Water. In its effort to trace how White writers constructed the naturalness of White British domination in Canada, White Civility is silent about these important texts, and in this way runs the risk of reproducing the sanctioned forms of ignorance ${ }^{8}$ that assume only White people published works of consequence in Canada's formative years, or that, if non-White authors did write, they were either exceptions or what they wrote was ephemera, hardly constituting the canon of the nation's literary archive. If the signifiers of race are floating and sloppy, the realms of sanctioned ignorance that reinforce racial hierarchies have a staying power that makes them consistent and self-replicating.

So, why, ask all three critics in their expression of a third broad concern, hold on to the concept of civility as I do in my concluding call for "wry civility"? Doesn't the concept itself lock us to the same old epistemologies and their sanctioned forms of ignorance, so that we cannot see or hear the alternatives around us? Collectively, Robert, Margery, and George put a finger on a major and important question for the future of the project of anti-racist critical work: where do you go after the critique? Okay, the book shows how civility in Canada has a contaminated, contradictory, violent history. Where do you go from here? Why not abandon the concept altogether? Clear the decks for other epistemologies, other ways of imagining a public sphere that are not so powerfully tied to the grievous inheritances of White, European, enlightenment-derived culture?

Theirs is a far-reaching and important question, and one that is far beyond my capacity to answer. But let me add my own observations and concerns to a question I believe is increasingly facing us all in a post-9/1 1 world. There is a curious way in which civility is under attack from at least two sides at once: from the perspective of anti-racism and social justice, civility is under attack from critics such as myself for its false pretences, for the ways in which it masks the violences it claims either to have avoided or resolved. We might call this the attack from below or from the margins, since it pays attention to the violence and suppression 
at the borders of the civil sphere. But civility is also under concerted attack these days from above, from the powers that be. In the panicked exceptionalism rationalized these days as a war against terror, basic rights to a fair trial are overlooked when those accused of terrorism are detained without due legal process in Guantanamo Bay; or in Canada, where five Muslim men have been detained without trial for as long as seven years under the provisions of the Security Certificate and were not given access to legal council or the opportunity to hear the nature of the charges against them. Basic civil rights are under attack when Canadian agents of the Canadian Secret Intelligence Service and the Royal Canadian Mounted Police participated in the heinous process of "extraordinary rendition" when by leaking false terrorist charges against Maher Arar to the Federal Bureau of Investigation, who then arranged to have him extradited to Syria, where they knew he would endure forms of torture that are illegal in Canada and the United States. These are some of the more sensational recent instances of the attack from above on basic civil provisions. They are instances of the contradictory structure of civility-the nightmare of the terrorist excuses the violence of the civilized as they shore up the borders of their civility. But Canadian civility has always suppressed its external and internal threats at the borders of whiteness: the racial profiling that reproduces the criminalization of Black young men in urban centres, or the civil, law-abiding methods by which Indigenous cultures have been deprived of ceremonial traditions or of treaty lands have become so common and prosaic that they often elude public notice as instances of the same repressive processes.

Nonetheless, the widespread indignation some Canadians have expressed at these abrogations of legal civil provisions is a reminder of the elements within these civil codes that are worth keeping. Canada does have provisions such as a Charter of Rights and Freedoms and Human Rights codes that offer mechanisms for restraining and reprimanding these abuses. And we should ask ourselves, in an era of heightened racial panic such as the present, whether a complete dismissal or rejection of civility might not risk playing readily into the hands of the abusers? Indeed, might not the critical attack from below play into the hands of the attack from above, as the academic and activist criticisms of the multiculturalism policy may have done when successive governments since the mid-1990s used them as excuses to cut funding to its various programs (see Stone and Young)? Given these very real dangers, I believe a strategic reorientation of the contradictory and contaminated concept of civility-what I call "wry civility"-offers more possibilities for raising anti-racist awareness than does a utopian rejection of the concept altogether.

To put it differently, I think a strategic enactment of a politics of fulfilment has better chances at this particular post-9/11 moment than does a 
politics of transfiguration. I am referring here of course to terms elaborated by Paul Gilroy in The Black Atlantic for two general kinds of political activity and expression that recurred throughout the African diaspora (see esp. 36-40). ${ }^{9}$ The politics of fulfilment, he explains, called upon bourgeois civil society to live up to its own declared egalitarian, universal values, which, in the context of the anti-slavery movement, would require the emancipation and enfranchisement of Africans who had been enslaved and excluded from the civil sphere. By contrast, the politics of transfiguration was a way in which enslaved or disenfranchised Africans expressed themselves despite the overdeterminations of White supremacy. This agency, this politics, he says, was expressed outside of or above the level of language by those slaves who stepped off the slave ships into the waters of the Middle Passage; or, again, it was expressed in the guttural expostulations and screams or other non-verbal vocalizations that were fundamental to diasporic African musical forms such as the blues or gospel spirituals. The politics of transfiguration is radically utopian, aspiring to transcend the limits of the existing social order, while the politics of fulfilment inhabits them, demanding that the existing structures-compromised, hypocritical, and contaminated as they are-realize the positive values outlined in their own rhetoric. I do not think Gilroy's point is to call for some absolute choice between these two forms of politics, for without a vision for utopia, without transcendence, how would one have the will or energy to go up against the recalcitrance of the status quo? Rather than forcing a choice, then, Gilroy's distinction enables us to see how they have been deployed strategically, perhaps in various combinations, and how we might deploy them given our varying circumstances, resources, and abilities. On the continuum between fulfilment and transfiguration, my call at the end of White Civility for an inhabitation of wry civility-for an effort to displace contented civility with contending civilities-leans more towards the politics of fulfilment. But because it engages with the social order as that order currently exists, wry civility runs the risk of being trapped within its terms and epistemologies, as Margery observed during our panel session. I believe it is worth the risk, even as I recognize that not everyone can afford the same risks with equal immunity.

I think the risk is worthwhile for two reasons. First, because I believe an utter rejection of civility plays right into the hands of today's elites who would be delighted by a populace that has become cynical and disinterested in the maintenance of basic civil protections. Second, I think the idea of abandoning civility to make room for other epistemologies and ways of being indulges the delusion of neutral consciousness, as if we will be able to see or hear anything new only if all previous data are wiped clean from our memories. If, as Dionne Brand's poetry has taught us, no language is neutral, neither is any eye or ear or consciousness. We 
do not leap out of our bodies, our histories, or our experiences into some pure space where our sensibilities become marvellously receptive to new, previously unthinkable understandings. What newness we can comprehend filters, instead, through our existing apparatus, through what our contexts and experiences have prepared us to know. This apparatus is capable of admitting something new only if it is confronted with challenges to its sedimented assumptions and procedures. This is why Margery's and George's second broad concern is so key: if all we ever hear, all we are ever exposed to, is the same set of voices and opinions, the same set of unspoken assumptions, the same canon of legitimate thinkers and ideas, we will never be able to shake loose the complacency of contented White civility.

My sense is that a "wry" or critical inhabitation of civility requires a multiple, decentred consciousness, one that is aware of a whole range of contending civilities - that is, of competing, contemporaneous conceptions of what constitutes the polity, of the different conceptions in any given collective of who "we" are, how "we" got here, what the protocols for constructive dialogue should be. Such an awareness does not attempt to colonize others' epistemologies by fantasizing that I can slip out of my own epistemological framework and completely understand someone else's; instead, it recognizes, as Ian Angus has argued, that the road to the universal passes through one's own particularity (see esp. 154-61). A better understanding of our own framework, one that does not disavow its self-defences and hidden violences, can be a step in opening our ears to the differences of others. But it is just a step, an early step. If we examine "our own" only, we will never hear the voice of any other, nor will we hear that many voices, a lively polyphony, fill the civil sphere.

It is in this context that Robert's query about my linkage of civility with civilization raises such an important point. ${ }^{10}$ In emphasizing the etymological link between civility and civilization in White Civility, I depart from Étienne Balibar who, in a footnote to his essay "Three Concepts of Politics: Emancipation, Transformation, Civility," wishes to keep the two distinct. "I choose the term civility," writes Balibar,

for its dual relationship with citizenship (civilitas was the Latin translation of politeia; the French word 'civilite' was first introduced by Nicolas Oresme in the sense of 'the institution or government of community', and hence as synonymous with what we call 'politics'-as indeed was the English term 'civility') and with morals, public and private (the sense of the Hegelian term Sittlichkeit).... I also prefer it to the term 'civilization' .... It should also be said that the term 'civilization' is not easily dissociated from 
the idea that there are barbarians and savages who have to be "civilized' (that is to say, in practice, subjected to the worst violence)" $(39$, n. 36).

I want to relink these two concepts of the civil-one as a concept of political-moral order and one as a temporal, progressive concept-in the idea of civility. For it seems to me that the violence Balibar ascribes to the temporal concept of civilization - that people deemed to be backwards or barbaric must be brought up to date and "civilized" by brutal means if necessary-must not be sundered from our understanding of the politics of "civility" if we are to displace the racial hierarchies and discriminatory injustices that have hidden within their mythos. ${ }^{11}$

In this sense, the European concept of civility-civilization is deeply invested in the single timeline or chronotope of what we might call Imperial Time, and one important way to displace its violent trajectory and open up to different epistemologies and new stories is to develop an awareness of contending, rather than single, civilities, and this awareness will involve cognizance of multiple, contemporaneous chronotopes. A remapping of our concepts of time is not the only terrain for displacing White civility, but because the assumptions of progress and improvement are so central to European, Christianity- and Enlightenment-derived conceptions of civilization, it is a particularly strategic place to start, and I will devote my remaining comments to sketching out what such a strategic intervention might look like. ${ }^{12}$ "Chronotope" (Gk. khronos, time + topos, place) is a word Mikhail Bakhtin borrowed from mathematics and biology, in his essay "Forms of Time and of the Chronotope in the Novel," to describe the mental maps or images we have of space and time. Images such as the road or the path of life, of going through the valley of sorrow, or riding off into the sunset are chronotopes. And these chronotopes are the ways in which we humans picture ourselves in a meaningful sequence that adds up to something, that is heading somewhere, and that makes sense of the bewildering happenstance of our daily round. We construct chronotopes in an ongoing dialogue between individual and collective experience, and much of our personal sense of belonging has to do with the fit between our individual time-space maps and those of the communities in which we live.

Although I do not use Bakhtin's term in White Civility, the book argues that the Canadian invader-settler narrative rises out of a particular chronotope that derives from the idea of civilizations racing each other for a place at the vanguard of progress. We could call this Isochronic, Imperial Time because it understands everyone in the world to be on a single timeline, with some cultures being more advanced and leading the way into the future while others are more primitive and "backward" (see Figure 1). 


\section{Figure 1}

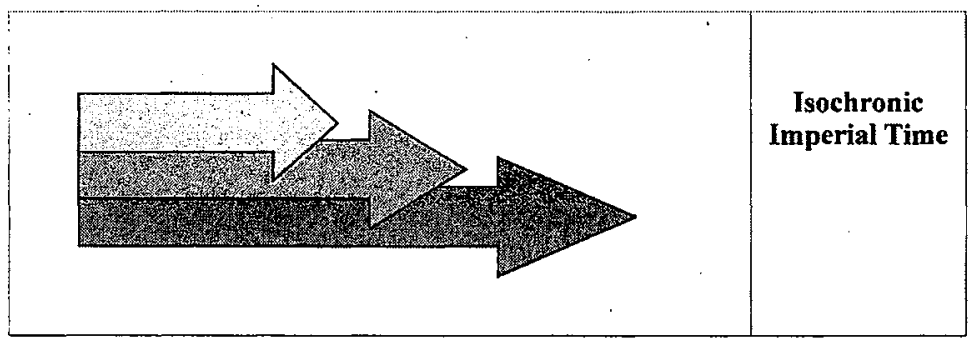

Isochronic, Imperial Time was at the heart of the European civilizing mission, but it is just as powerful today in the world systems theory that nominates some nations as developed nations and others as developing. Canada's status as an invader-settler nation made Canadians particularly anxious about their place in Isochronic, Imperial Time because they were aware of being a "new" nation, felt themselves to be belated in relation to the already established "advanced" nations in Europe or the United States. This chronotope, I suggest, has made Canadians nervous, even somewhat hysterical, in our claims for our own civility: we may not be as rich or "developed" as some other countries, but we regularly indulge a compulsion to insist we are more civilized than they are.

But Canadian White civility is shaped by other chronotopes as well: and we might call one of these Nation-based Post-Colonial Time. ${ }^{13}$ When conceived on the collective, national scale, Nation-based Post-Colonial Time marks its beginning as the moment when the colony cut its ties to its colonial parent and became an independent nation, and when this kind of time is conceived on the personal or familial scale, it tends to trace "our" (invader-settler) beginnings to the pioneer generation that settled in the Americas. Frequently, the Atlantic Ocean marks the cut or distance from the Old World and the ancestors there about whom we know very little. The American version of Nation-based Post-Colonial Time exhibits a cleaner break from its Old World European origins than does the Canadian version, symbolized by the $\mathrm{X}$ as opposed to the slash mark in Figure 2, while both versions imagine the divide as marking the beginning of local, national progress and improvement, figured by the arrow pointing to an ascending future. 


\section{Figure 2}

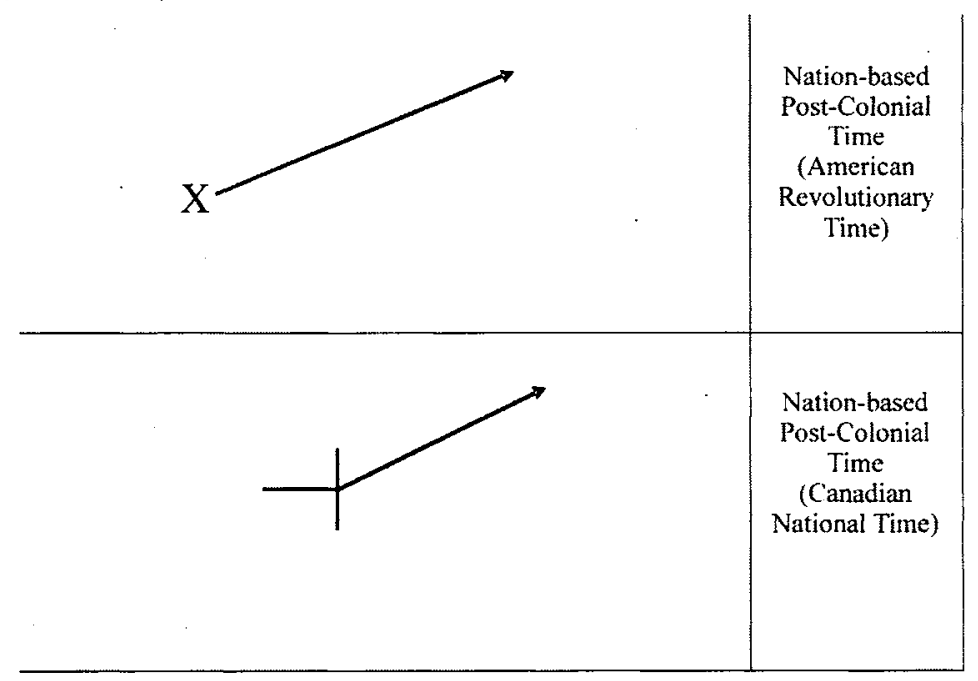

Whereas the American version emphasizes the absolute cut from the British past at the Revolution and tends to disavow the pre-Revolutionary past in the interests of the cult of the future and manifest destiny, the Canadian version, as we might expect, presents a more ambiguous chronotope in which the cut from Britain (and France) is much less complete: the Loyalists and Habitants were seen to have continued the best of the British and French traditions in what for them was the New World, even as the freedom of movement in the New World liberated them from some of the heavy protocols of class and social status in Europe. Thus, the Canadian yersion of the Post-Colonial chronotope imagined a continued link to the old countries even as it imagined the New World as enabling an improvement upon European ways of life. In both versions, however, the chronotope of Nation-based Post-Colonial Time assumes the overall trajectory of Imperial, Isochronic Time in its disavowal of pre-existing Indigenous civilizations and its imagination of the establishment of the United States or Canada as a "fresh start" in history. ${ }^{14}$

But the pioneer tradition is not, of course, the only chronotope operating in Canadian consciousness; indeed, for many Canadians nowadays it is a fairly remote, less and less relevant, time-space image of where we came from and where we are heading. The successive waves of immigration throughout the twentieth century have given rise to what we might call the chronotope of Diasporic Displacement. In this chronotope, cultural groups retain their image of themselves in time by reference to the trauma of displacement, whether it be Mennonites recalling the purges in Russia, Jews recalling the pogroms and Holocaust, Caribbean people recalling the displacements of slavery and colonialism, or Somalis fleeing the breakdown of civil government in their original homeland (see Figure 3). ${ }^{15}$ 
Figure 3

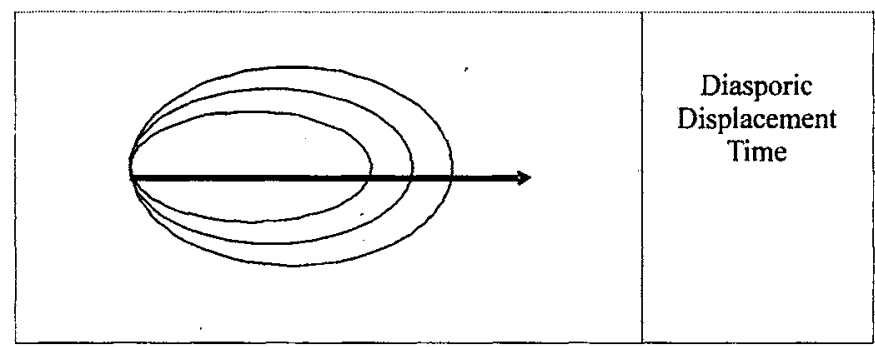

In many ways, the idea of multiculturalism in Canada assumed, in its first instances, that the nation was composed of groups who each had their own chronotope of displacement and who could be good Canadian citizens by keeping alive the narratives of this displacement. Canadian civility, in this view, meant imagining Canada as a haven for various chronotopes of displacement. But the concept of haven suggested a haven of rest, with the implication that eventually, diasporic peoples would assimilate and integrate into Canadian life, so that the trauma and urgency of these narratives would, in time, subside. In this sense, the idea of multicultural welcome contained within it a kind of shelf life or expiry date for diasporans, who, having found their feet again in Canada, would presumably identify more and more as Canadians and less and less as diasporans. ${ }^{16}$ Thus, the forward-moving single line in Figure 3 retains, despite the elliptical recurrences of traumatic memory, a sense of Imperial Isochronic Time-it points to the belief that eventually, the traumatic and barbaric past will give way to a progressive, civil future.

But, of course, one of the most powerful kinds of displacement that has taken place in Canada, and which continues to take place in Canada, is the displacement of Aboriginal peoples. Very often, the chronotopes of Nation-based Post-Colonial Time and of Diasporic Displacement Time have shouldered aside and obscured the ongoing displacements of Indigenous people in Canada. Here I am less confident of what kind of graphic can best represent Aboriginal concepts of time, but for the sake of explanation, let us provisionally consider the image of time as the concentric circles in the trunk of a tree or the ripples that emanate from a stone thrown into a pool (Figure 4). 


\section{Figure 4}

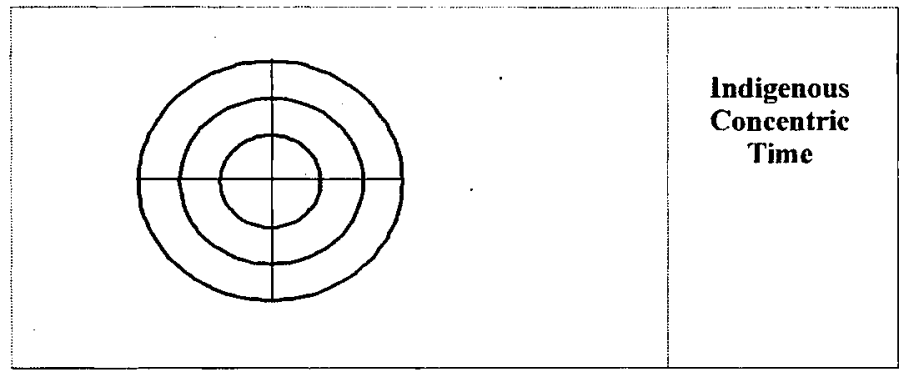

Here, rather than imagining time as moving along Imperial Isochronic Time's linear path into the future, or, as in Post-Colonial Time, having made dramatic departures or cuts from the past, the understanding of time is not, in the words of Vine Deloria Jr., based on "rigid chronology" with its assumptions of specific incidents "dividing human time experience into a before and after" ("The Concept of History" 291), but rather as a "growth process, which is to say that time has qualitative packets of quanta that are regulated by the amount of time it takes an organism or entity to complete a step of maturation" ("If You Think About It" 57). Think of the circles in the tree, which are the physical manifestation of the seasons' varying circumstances of moisture, drought, winter or fire that shaped the tree's growth and maturation. Deloria, generalizing about Indigenous epistemologies from the example of Western Sioux philosophy, says that the circular formation of knowledge meant that "there were no ultimate terms or constituents of their universe, only sets of relationships" and that these relationships were renewed in ceremony, whose "center itself represents all possible times taking place simultaneously" $(48,55)$. The crossed lines in the diagram refer to the four ceremonial directions at the same time that they emphasize the specificity of place and land at the centre of this understanding of time. The point here is that the past, in the image of concentric circles, is not placed in a line of progression where it is seen as superseded by the present, which will soon in turn be overtaken by the future. The past is in the centre of ongoing life, which is why it is consulted, renewed, interpreted in the present.

In the Okanagan' N'silxchn language, writes Jeannette Armstrong, "[t]ime, place, and things are all made into movement, surrounding you and connected to you like the waves of a liquid stretching outward" ("Land Speaking" 190). Speaking N'silxchn, she says, "I step into vastness and move within it through a vocabulary of time and of memory. I move through the vastness into a new linking of time to the moment I speak" (183). On the one hand, there is a concept of a "time that is no 
more," but, on the other, that distant time remains animate in the land and its human and non-human inhabitants as a continuing presence. This understanding of the ever-presence of the past is embedded in N'silxchn concepts of language itself, as expressed in this excerpt from Armstrong's poem "Words":

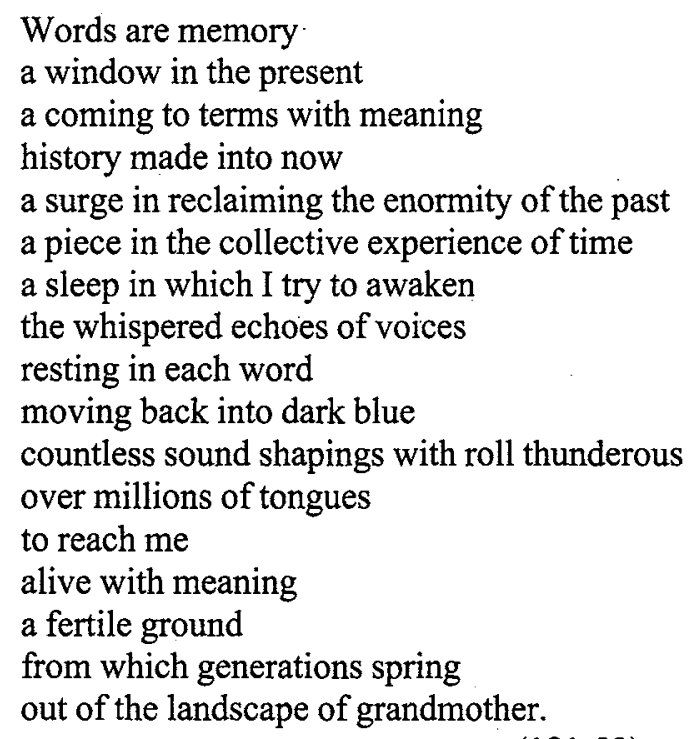

As Armstrong explained in the keynote presentation she gave at the ACLALS conference two days before the panel on White Civility, the words that define membership in the N'silxchn-speaking community enjoin each member to take an ember or strand from the life force that is always spiraling out from the centre of the land's community and to renew it by retelling and reinterpreting it in the present. The civil sphere, in this chronotope, is not invested in a race for the future, nor a cut from the past, nor a recollection of an irrecoverable distant land. The people see themselves not as on a linear path from the past to the future, but as inhabiting an ever-present continuous chronotope: the past is like a lifegiving fire burning or a thread being spun at the centre of the culture, and the land, with its community of human, plant, and animal inhabitants, is this centre. The idea of civil organization, then, the idea of the polity, imagines each member or generation taking his or her ember or thread, and blowing on that ember, or weaving or spinning these many strands into a productive or harmonious whole. This chronotope imagines time and space as present, moving and dynamic, simultaneously centripetal and centrifugal, as concentric and inclusive. ${ }^{17}$ 
I sketch these four chronotopes of Isochronic Imperial Time, Nationbased Post-Colonial Time, Diasporic Displacement Time, and Indigenous Concentric Time, not to establish them as absolute models, but as explanatory devices, ways of trying to help us see how a diverse civil society cannot establish any one of these chronotopes as its sole narrative if we are to understand ourselves, our neighbours, our culture, and the dynamics between the various communities within Canada. What we need-and I would call it a form of wry civility-is a consciousness of multiple and simultaneous chronotopes, of very different concepts of time and space, of where different ones among us come from and where we variously are in the present, and we need to try to hold more than one of them simultaneously. A sense of multiple chronotopes might help foster humility and an awareness of the contingency of our own mental frameworks and conceptual maps, and this humble awareness in turn can have a remarkable impact on real attitudes and in real life.

I grew up the child of Canadians who worked in Ethiopia, which was an excellent place to get a crash course in multiple chronotopes. Ethiopia follows the Julian calendar, because of its long history of Eastern Orthodox faith, and this calendar is seven years "behind" (for lack of a better term) the Gregorian calendar followed by most European and American countries. What this means is that this year-2007 for us-is Y2K for Ethiopians. But people. in Ethiopia have not spent this year hunched over their computers trying to make sure they don't crash when the New Year rolls around. They have not felt the need because they had already seen that the Gregorian world got very anxious about the possibility of doomsday at the approach of the millennium, which then passed with hardly a ripple. In other words, Ethiopians had a chance to watch other people go through a parallel chronotope, and being able to witness more than one chronotope can give you a wry perspective on your own, a sense of its relativity, and of its being contiguous with other chronotopes. The result, I think, is a form of wry civility, a sense that one's own destination, one's own life path, are not the only ones, that there are other paths and processes, and that they parallel and even intersect with one's own. The consciousness of multiple, simultaneous chronotopes, therefore, can be one way to produce a healthy wry civility, right here in the middle of our contaminated, unfulfilled political culture; a civility that refuses to deny or suppress the violences of the present order but, because of its dialogical or comparative awareness, can glimpse the possibilities for other traditions of civility that are not hopelessly tied to the dominant assumptions of whiteness and Britishness outlined in White Civility. 


\section{Notes}

1. Many thanks to Jill Didur and Susan Gingell, who brought the idea of the Author Meets Critics panel sessions to the Canadian literary critical community, and who have now convened two such sessions, the first at the CACLALS annual conference in 2006 and this second one at the ACLALS triennial conference of 2007.

2. For the purposes of consistency, I use the upper-case for racializing words that refer to people whether as nouns or adjectives-thus, 'Blacks,' 'White settler,' 'Aboriginal knowledge,' and so on-because they parallel the national and ethnic uses of similar terms such as 'Canadian,' 'Chinese,' or 'Mohawk.' I use lowercase when I am referring to the conceptualization of these categories-thus, 'whiteness,' 'blackness,' 'indigeneity,' etc. This distinction is extremely difficult to maintain consistently because the conceptualization cannot be separated from the capacity of these terms to refer to people. I have come to the conclusion that there is no adequate system for referring to these racialized terms, and that their typographical awkwardness and inconsistency are signs of their constant capacity for mutation and reinvention.

3. In his massive and influential work The Civilizing Process (1936, 2000), Norbert Elias notes that the temporal idea of civilization as a process was foundational to the very first known use of the term civilization as a noun by the French nobleman Mirabeau the Elder in the 1760s: noting Mirabeau's criticism that courtly claims of civilization were more pretence than accomplishment, and that they had not yet been animated as actual virtues, Elias observes that at the very origin of the concept of civilization, then, is the idea that "Civilization is not only a stage, it is a process which must be taken further." This concept, then, made civilization part of the temporal discourse of reform and social-moral improvement (41). I will have more to say about the relations between civility and civilization below.

4. See Elias pp. $365 \mathrm{ff}$. for a discussion of how the notion of the civil state as providing the conditions for an orderly, peaceable society required the monopolization of violence by the state.

5. "The conventional picture," writes Akenson, "is that a 'British' culture inherited from the homeland (indirectly, in the Loyalist case) was modified by the new physical environment and catalysed by participation in imperial wars, and thereby emerged the New Zealand, Australian, or English-speaking Canadian identity. The study of the process of cultural transfer in general, and of ethnicity in particular, indicates that the process was more complex than that. There was no 'British' culture to draw on, but, instead, there were several vigorous, distinct, and, in many of their details, incompatible Anglo-Celtic cultures found in the homeland. Therefore, an integral and absolutely necessary aspect of the development of a sense of identity was the creation of a 'British' culture in the new homeland, one that did not in fact exist in the old. The melding of the several Anglo-Celtic cultures to establish a new and synthetic 'British' culture was coterminous with the creation of the new national identities. Thus, when one sees Scots, English, Welsh, and Irish accepting in many contexts the term 'British' in Canada, Australia, and New Zealand, one is actually seeing the completion of the 
first step of their escape from the cultural hegemony of the Old World metropoles. It was then only a short step from being 'British' to being a Canadian, an Australian, or a New Zealander" (396-97).

6. I chose to study the Scottish invention of English Canada because of the clear dominance that Scots have had in every powerful sector of Canadian societyincluding industry, media, politics, education, and religion. A similar process also benefited Irish immigrants to Canada, but because they generally migrated later, and they were predominantly Catholic, not to mention their less-than-solid hold on whiteness (see Ignatiev; Roediger), they had a much smaller role in defining the specific form of Britishness that shaped the concept of white civility in Canada.

7. Martin Barker, writing in the Thatcher era in the early $1.980 \mathrm{~s}$, has called this use of cultural difference to rationalize racial exclusions the "new racism" in his book by the same title.

8. See Spivak's use of the term sanctioned ignorance in Death of a Discipline (9).

9. I am grateful to Cory Lavender, who, in the writing of his thesis in the summer of 2007 , reminded me of the salience of Gilroy's terms.

10. Robert specifically asked about the variances between the French and English usages of these terms, particularly "civilization" as a French rather than English concept. See Elias pp. 6-10 for a discussion of how 16th and 17th-century French and English understandings of civilization assumed a very similar concept of courteous manners and cultivation; the French and English versions differed more decisively from the German concept of Zivilization, which disparaged the showy manners of the upper classes in comparison with the middle-class virtue and solidity of what Germans called Kultur. In Canada, the differences between French and English concepts of civility and civilization became increasingly blurred, for, as Michael Dorland and Maurice Charland demonstrate in Law, Rhetoric, and Irony in the Formation of Canadian Civil Culture, the transfer from New France to British North America after 1759-60, and particularly as codified in the Quebec Act of 1774, involved the accommodation of French civil law within or underneath British common law (77-117). As they demonstrate in their careful reading of the complex social thetoric that evolved from this blending and (mis)translation of legal systems, Canada has never been able to trace its discursive lineage, even in the basic arrangements of civil society, to a single source (191).

11. See Elias for a thorough history of the evolution of the concept of civilite from Erasmus's De civilitate morum puerilium (On civility in boys) of 1530 (47-8), through its development as polite deportment and sophistication in the French court (32) and onwards into the notion of the civilized as those who restrain their own behaviour in the interests of an orderly social sphere ( $365 \mathrm{ff}$.). See also his discussion of civilization as a temporal concept for social progress that colonizing nations saw themselves as having already achieved and other "primitive" nations as lacking (43).

12. See Vine Deloria Jr.'s essay, "The Concept of History," excerpted from his God Is Red: A Native View of Religion (1994) and reprinted in Spirit and Reason: The 
Vine Deloria Jr. Reader (1999), for a discussion of how the Judeo-Christian concept of unilinear time (from creation to apocalypse) forms the basis of the Western concept of time, with its exclusions of Chinese, Indian, or tribal histories and temporalities.

13. I am influenced in my choice of terms here by Thomas King's much anthologized essay "Godzilla vs. Postcolonial," where he objects to the idea of postcolonial criticism because the chronotope purveyed by the term assumes colonial contact as the watershed of history, once again denying the Indigenous forms of expression and civil organization that had their own timelines and trajectories independent of European arrival (see especially pp. 242-43).

14. There are, of course, other chronotopes of early colonial thinking that could be sketched out here, including the Christian images of the New World as a new Eden or a place where a New Jerusalem might be built. But I will not comment on other possibilities here, since my point is simply to indicate the various assumptions of civility and civilization borne within these chronotopes.

15. Many theorists of diaspora have discussed the collective remembrance of trauma as central to the constitution of a diaspora; see, for only two examples, Cohen, ch. 1 , and Mishra.

16. This assumption has been denied in recently published research by University of Toronto sociologists Jeffrey Reitz and Rupa Banerjee which indicates that "Visible-minority immigrants are slower to integrate into Canadian society than their white, European counterparts, and feel less Canadian, suggesting multiculturalism doesn't work as well for non-whites" (see Jiménez).

17. I do not have room in this paper to enter into a prolonged discussion of Lee Maracle's fascinating engagement with time in charting the process of her protagonist's healing in the remarkable novel Daughters Are Forever (2002). The novel shows how the violent history of North America has produced a chronotope of stillness or of being under siege within Turtle Island women, and that this stillness makes First Nations women passive in the face of Western cultural invasion. Knowing that Native women's condition of dispassion had "taken over one hundred years to create" (55), Marilyn, the protagonist, gradually realizes that "Time is a crucial illusion" $(64,141)$ and that healing will require a reinvigorated ability "to live within the boundaries of its illusion, make reality spring from it, or hook her being firmly to it" $(64,141)$. By reconnecting with her own passion and thereby regaining the spiritual energy and courage to restore relationships around her, Marilyn begins a process of healing represented by the new intergenerational relationships signaled at the end of the novel among herself; a social worker deeply invested in the twentieth-century struggles of First Peoples (from the AIM movement to Oka and Ipperwash); the traditional, nineteenth-century-like healer, Dolly; and Marilyn's twenty-first-century-bound daughters, Cat and Lindy-all contemporaneously in the present (250). 


\section{Works Cited}

Akenson, Donald Harman. "The Historiography of English-Speaking Canada and the Concept of Diaspora: A Sceptical Appreciation." The Canadian Historical Review 766.3 (September 1995): 375-409.

Angus, Ian. A Border Within: National Identity, Cultural Plurality, and Wilderness. Montreal: McGill-Queen's UP, 1997.

Armstrong, Jeannette. "Land Speaking." Speaking for the Generations: Native Writers on Writing. Ed. Simon J. Ortiz. Tucson: U of Arizona P, 1998. 175-94.

- . "Literature of the Land: An Ethos for These Times." Unpublished paper presented as keynote presentation at "Literature for Our Times," the $14^{\text {th }}$ International Triennial Conference of ACLALS, University of British Columbia, August 17-22, 2007.

Balibar, Étienne. "Three Concepts of Politics: Emancipation, Transformation, Civility." Trans. Chris Turner. Politics and the Other Scene. Trans. Christine Jones, James Swenson, Chris Turner. London: Verso, 2002. 1-39.

Bakhtin, Mikhail. "Forms of Time and of the Chronotope in the Novel: Notes Towards a Historical Poetics." The Dialogic Imagination: Four Essays by M.M. Bakhtin. Ed. Michael Holquist. Trans. Caryl Emerson and Michael Holquist. Austin: U Texas P, 1981. 84-258.

Barker, Martin. The New Racism. London: Junction Books, 1981.

Clarke, George Elliott, ed. Fire on the Water: An Anthology of Black Nova Scotian Writing. 2 vols. Lawrencetown Beach, NS: Pottersfield Press, 1991.

Cohen, Robin. Global Diasporas: An Introduction. Seattle: U Washington P, 1997.

Deloria Jr., Vine. "The Concept of History." 1994. In Spirit and Reason. 290-304.

_. "If You Think about It, You Will See that It Is True." 1993. In Spirit and Reason. 40-60.

- Spirit and Reason: The Vine Deloria Jr. Reader. Ed. Barbara Deloria, Kristen Froehner, and Sam Scinta. Golden, CO: Fulcrum Publisher, 1999.

Dorland, Michael and Maurice Charland. Law, Rhetoric, and Irony in the Formation of Canadian Civil Culture. U Toronto P, 2002.

Eigenbrod, Renate. Travelling Knowledges: Positioning the Im/Migrant Reader of Aboriginal Literatures in Canada. Winnipeg: U of Manitoba P, 2005.

Elias, Norbert. The Civilizing Process: Sociogenetic and Psychogenetic Investigations. 1936. Trans. Edmund Jephcott. Rev. ed. Ed. Eric Dunning, Johan Goudsblom, and Stephen Mennell. Oxford: Blackwell, 2000.

Gilroy, Paul. Against Race: Imagining Political Culture beyond the Color Line. Cambridge, Mass: Belknap of Harvard UP, 2000.

- The Black Atlantic: Modernity and Double Consciousness. Cambridge, MA: Harvard UP, 1993.

Hall, Stuart. Race, the Floating Signifier. Film directed by Sut Jhally. Media Education Foundation, 1996.

Ignatiev, Noel. How the Irish Became White. NY: Routledge, 1995.

Jiménez, Marina. "How Canadian Are You?" The Globe and Mail 12 Jan 2007: A1. 
King, Thomas. "Godzilla vs. Postcolonial." New Contexts of Canadian Criticism. Eds. Ajay Heble, et al. Peterborough: Broadview, 1997. 241-48.

Kostash, Myrna. "Imagination, Representation, and Culture." Literary Pluralities. Ed. Christl Verduyn. Toronto: Broadview/Journal of Canadian Studies, 1998. 92-6.

Maracle, Lee. Daughters Are Forever. Vancouver: Polestar/Raincoast Books, 2002.

Mishra, Vijay. "The Diasporic Imaginary: Theorizing the Indian Diaspora." Textual Practice 10.3 (1996): 421-447.

Monture, Rick. "'in the free and independent manner natural to Indians': Joseph Brant and the Translation(s) of Iroquois Sovereignty." Unpublished paper delivered to the American Studies Association, Washington D.C., November 5, 2005.

Roediger, David. The Wages of Whiteness: Race and the Making of the American Working Class. NY: Verso; 1991.

Slipperjack, Ruby. Silent Words. Saskatoon: Fifth House, 1992.

Spivak, Gayatri Chakravorty. Death of a Discipline. NY: Columbia UP, 2003.

Stone, Marjorie. "The Research Matrix, the Metropolis Project, and Multiculturalism Program Critiques: Bridging Strategies for Knowledge Mobilization in the Humanities:" Unpublished paper presented at "The Culture of Research: Retooling the Humanities." University of Guelph/TransCanada Institute, 20-22 October 2006.

"The Celts." The People of Ireland. 21 September 2007 at http://www.irelandseye. com/irish/people/settlers/celts1.shtm.

Titley, Brian E. A Narrow Vision: Duncan Campbell Scott and the Administration of Indian Affairs in Canada. Vancouver: UBC Press, 1986.

Trevor-Roper, Hugh. "The Invention of Tradition: The Highland Tradition of Scotland." The Invention of Tradition. Ed. Eric Hobsbawm \& Terence Ranger. Cambridge \& London: Cambridge UP, 1983. 15-41.

Woo, Grace Li Xiu. "Canada's Forgotten Founders: The Modern Significance of the Haudenosaunee (Iroquois) Application for Membership in the League of Nations." Law, Social Justice, and Global Development. Retrieved December 12, 2006 at http://elj.warwick.ac.uk/global/03-1/woo.html.

Young, Judy. "No Longer 'Apart'? Multiculturalism Policy and Canadian Literature." Canadian Ethnic.Studies 23.2 (2001): 88-116. 